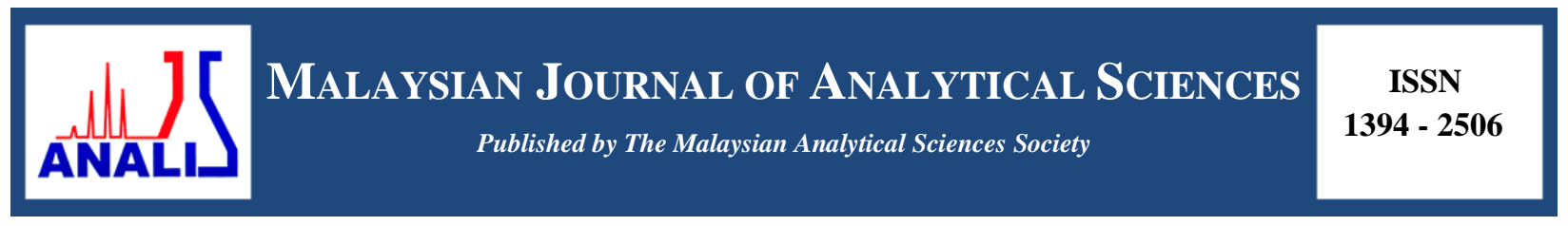

\title{
RAPID SPECTROPHOTOMETRIC METHOD FOR HISTAMINE DETERMINATION IN FISH USING ALIZARIN RED S AND METAL
}

\section{(Kaedah Spektrofotometri Pantas untuk Penentuan Histamin dalam Ikan Menggunakan Alizarin Merah S dan Logam)}

\author{
Miftakhul Jannatin ${ }^{1}$, Ayu Nabila Izazi Latjuba ${ }^{1}$, Sri Wahyuni ${ }^{1}$, Ganden Supriyanto ${ }^{1,2} *$, Wan Aini Wan Ibrahim ${ }^{3}$ \\ ${ }^{I}$ Department of Chemistry, Faculty of Science and Technology \\ ${ }^{2}$ Laboratory of Sensor and Biosensor, Institute of Tropical Disease \\ Universitas Airlangga, Jl. Mulyorejo Kampus C UNAIR Surabaya 60115, Indonesia \\ ${ }^{3}$ Department of Chemistry, Faculty of Science, \\ Universiti Teknologi Malaysia, 81310 UTM Johor Bahru, Johor, Malaysia \\ *Corresponding author: ganden-s@fst.unair.ac.id
}

Received: 25 October 2017; Accepted: 22 January 2019

\begin{abstract}
An analytical method for the determination of histamine using metals and alizarin red S (ARS) reagents by UV-Visible spectrophotometry was developed. $\mathrm{Cu}(\mathrm{II}), \mathrm{Co}(\mathrm{II})$ and ARS were used to form colored complex with histamine. The developed method was used to detect qualitatively and quantitatively the presence of histamine. Absorbance of $\mathrm{Cu}$ (II) and $\mathrm{Co}$ (II) complex were measured at a maximum wavelength of 505.5 and $567 \mathrm{~nm}$, respectively. Optimization of analytical parameters such as concentration of metals, concentration of ARS, sample solution $\mathrm{pH}$, and optimum time for complex formation were performed. Experimental results showed that the optimum concentration of $\mathrm{Cu}$ (II) was $50 \mathrm{ppm}, 75 \mathrm{ppm}$ ARS, sample solution pH 6 , and 15 minutes optimum time, while the optimum concentration of Co(II) was $125 \mathrm{ppm}$, ARS was 75 and 50 ppm, sample solution pH 5 and 10 minutes optimum time. Method validation indicated that the coefficient of variation, limit of detection $(\mathrm{LOD})(\mathrm{S} / \mathrm{N}=3)$, and limit of quantitation ( $\mathrm{LOQ}=10 \mathrm{~S} / \mathrm{N}$ ) of $\mathrm{Cu}(\mathrm{II})$ were $0.65 \%, 8.94 \mathrm{ppm}$, and $29.82 \mathrm{ppm}$ respectively with a sensitivity of $0.0054 \mathrm{ppm}$ and linearity of 0.9959 . Accuracy of histamine determination through Cu-ARS-histamine complex at a concentration of 50, 100, and $150 \mathrm{ppm}$ were $105.7 \%(\mathrm{RSD}=0.777 \%, \mathrm{n}=3), 105.06 \%(\mathrm{RSD}=0.606 \%, \mathrm{n}=3)$, and $94.12 \%(\mathrm{RSD}=0.767 \%, \mathrm{n}$ $=3$ ), respectively. Meanwhile, the CV, LOD, and LOQ of Co(II) were $0.28 \% ; 2.58$ ppm; and 8.6 ppm respectively with a sensitivity of $0.0006 \mathrm{ppm}$ and linearity of 0.9965 . Accuracy of histamine determination through Co-ARS-histamine complex at a concentration of 50,75, and $125 \mathrm{ppm}$ were $98.33 \%, 95.83 \%, 93.88 \%$, respectively. The proposed method was successfully applied to the determination of histamine in a fish sample with quantitative recovery; for $\mathrm{Cu}$ (II) complex (99.23\%) and $\mathrm{Co}$ (II) complex $(102.62 \%)$.
\end{abstract}

Keywords: histamine, metals, $\mathrm{Cu}(\mathrm{II}), \mathrm{Co}(\mathrm{II}), \mathrm{ARS}, \mathrm{UV}$-visible spectrophotometry

\begin{abstract}
Abstrak
Kaedah analisis untuk penentuan histamin menggunakan logam dan reagen alizarin merah S (ARS) telah dibangunkan menggunakan spektrofotometri ultralembayung-nampak. $\mathrm{Cu}(\mathrm{II}), \mathrm{Co}(\mathrm{II})$, dan ARS digunakan untuk membentuk kompleks berwarna dengan histamin. Kaedah yang telah dibangunkan digunakan untuk mengesan histamin secara kualitatif dan kuantitatif. Serapan kompleks $\mathrm{Cu}(\mathrm{II})$ dan $\mathrm{Co}(\mathrm{II})$ diukur pada panjang gelombang maksimum masing-masing $505.5 \mathrm{dan} 567 \mathrm{~nm}$. Pengoptimuman parameter analisis seperti kepekatan logam, kepekatan ARS, pH larutan sampel, dan masa optimum bagi pembentukan kompleks telah dilakukan. Keputusan eksperimen menunjukkan bahawa kepekatan optimum $\mathrm{Cu}$ (II) ialah 50 ppm, 75 ppm ARS, pH 6 larutan sampel, dan masa optimum 15 minit, manakala kepekatan optimum Co(II) ialah 125 ppm, ARS ialah 75 dan 50 ppm, pH larutan sampel 5 dan 10 minit masa optimum. Pengesahan kaedah menunjukkan bahawa pekali variasi (CV),
\end{abstract}




\section{Jannatin et al: RAPID SPECTROPHOTOMETRIC METHOD FOR HISTAMINE DETERMINATION IN FISH}

USING ALIZARIN RED S AND METAL

had pengesanan (LOD) $(\mathrm{S} / \mathrm{N}=3$ ) dan had kuantititatif (LOQ = $10 \mathrm{~S} / \mathrm{N}) \mathrm{Cu}(\mathrm{II})$ masing-masing adalah $0.65 \%, 8.94 \mathrm{ppm}$ dan 29.82 ppm dengan sensitiviti 0.0054 ppm dan kelinearan 0.9959. Ketepatan penentuan histamin melalui kompleks Cu-ARS-histamin pada kepekatan 50, 100, dan $150 \mathrm{ppm}$ ialah 105.7\% $(\mathrm{RSD}=0.777 \%, \mathrm{n}=3), 105.06 \%(\mathrm{RSD}=0.606 \%, \mathrm{n}=3)$, dan $94.12 \%(\mathrm{RSD}$ $=0.767 \%, \mathrm{n}=3$ ), sementara itu,CV, LOD, dan LOQ Co(II) masing-masing adalah $0.28 \% ; 2.58$ ppm dan 8.6 ppm dengan kepekaan 0.0006 ppm dan kelinearan 0.9965. Ketepatan penentuan histamin melalui kompleks Co-ARS-histamin pada kepekatan 50, 75, dan 125 ppm masing-masing adalah 98.33\%, 95.83\%, dan 93.88\%. Kaedah yang dicadangkan berjaya digunakan untuk menentukan histamin dalam sampel ikan dengan pengembalian kuantitatif untuk kompleks $\mathrm{Cu}$ (II) (99.23\%) dan kompleks Co(II) $(102.62 \%)$.

Kata kunci: histamin, logam, $\mathrm{Cu}(\mathrm{II}), \mathrm{Co}(\mathrm{II})$, alizarin merah S, spektrofotometri ultralembayung-nampak

\section{Introduction}

Histamine with chemical formula $\mathrm{C}_{5} \mathrm{H}_{9} \mathrm{~N}_{3}$ is a is a small-molecule hormone present in essentially all mammalian tissues which acts at the central nervous system level and in the regulation of sleep [1]. Histamine is produced in species of the Scombroidae family such as tuna and mackerel, mahi-mahi, blue fish, and sardine [2]. Histamine is one of the most toxic and most commonly found in foods and its concentration is frequently regarded as one of the biomarkers for quality control during the food production, transportation and marketing [3, 4]. Nowadays, an increased consumption of fish has been recommended due to its health promoting properties. However, some fish can cause histamine poisoning if its quality is not assured [5].

As a result, there were some regulations about histamine level in food. Based on Standard Nasional Indonesia (SNI) 01-2360 year 2008, histamine maximum limit in Indonesian fish is $100 \mathrm{mg} \mathrm{kg}^{-1}$. The European Commission has made a regulation of safety requirements on the histamine presence in seafood with amounts lower than $10 \mathrm{mg} / \mathrm{kg}$ of histamine which indicate that fish has good quality, a level of $30 \mathrm{mg} / \mathrm{kg}$ suggests significant deterioration, and a content of $50 \mathrm{mg} / \mathrm{kg}$ or higher is an evidence of definite decomposition [6]. While the United States Food and Drug Administration (FDA) has established $50 \mathrm{ppm}$ of histamine as the chemical index for fish spoilage [7]. Based on the assessment of poisoning cases, the guidance levels suggested for histamine content in seafood are: $<50 \mathrm{ppm}$ for safe consumption; $200-1000 \mathrm{ppm}$ as probably toxic; and $>1000 \mathrm{ppm}$ as toxic and unsafe for human consumption $[8,9]$.

Several analytical methods have been developed for the analysis and determination of histamine levels such as ultrasensitive flow injection electrochemical [10], lignin modified glassy carbon electrode [11], thin layer chromatography (TLC) [12], high performance liquid chromatography (HPLC) [13], ${ }^{1} \mathrm{H}$ NMR [14], electrochemiluminescence [15], liquid chromatography tandem mass spectrometry [16], polymerase chain reaction/denaturing gradient gel electrophoresis (PCR-DGGE) [3] and spectrophotometry [17]. Complex reaction between histamine, $\mathrm{Co}(\mathrm{II})$ and oxalate has been reported [18] with the complex structure shown (Figure 1), but it has not given a significant change of wavelength and solution color. On the other hand, alizarin red S (ARS) with chemical structure shown (Figure 2) is well known to form colored complex with metallic and organic compounds such as $\mathrm{Al}(\mathrm{III})$ [19], $\mathrm{Cu}$ [20], $\mathrm{Co}$ and $\mathrm{Ni}$ [21], $\mathrm{Cu}, \mathrm{Co}, \mathrm{Ni}$ and cysteine [22], and Ni-histamine [23] with a wide range of ARS solvents.
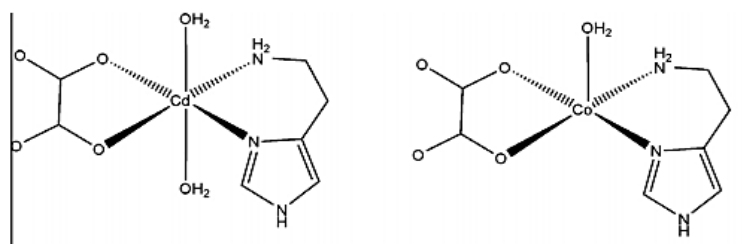


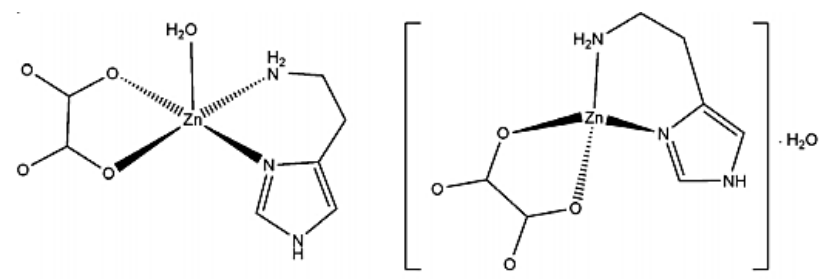

Figure 1. Complex structure of histamine-metal-oxalate [19]

The presence of a quinoid oxygen, with two hydroxyl groups at the $\alpha$ - and $\beta$-positions in ARS makes it very suitable for chelation, and its derivatives are well known colorimetric reagents with several applications. Furthermore, the presence of sulphonate groups in the molecule improves its reactivity [25]. ARS dye can exist in different forms depending on the type of media used, so this study used ARS as a complexing and coloring agent in the determination of histamine.<smiles>O=C1c2ccccc2C(=O)c2c1cc(S(=O)(=O)O)c(O)c2O</smiles>

Figure 2. Chemical structure of ARS

In this study, a novel spectrophotometric method for determination of histamine has been developed based on histamine-metal-ARS complex formation. Analytical procedure for the determination of histamine is based on the complex's reaction, which can form a colored compound and then the absorbance was measured using UV-visible spectrophotometer. Optimization of metal concentration, ARS concentration, solution $\mathrm{pH}$ and time for formation of complexes have been investigated as well. The analytical validation parameters namely LOD, LOQ, sensitivity, coefficient of variation $(\mathrm{CV})$, linearity, and accuracy were performed. The validated method was then applied to the determination of histamine in fish sample.

\section{Materials}

\section{Materials and Methods}

Histamine reference standard was purchased from Sigma Aldrich (Science Park Drive, Singapore). Copper sulphate hexahydrate, cobalt(II) nitrate hexahydrate, and ARS were purchased from Merck (Darmstadt, Germany). Methanol, sodium acetate, sodium hydrogen phosphate, sodium dihydrogen phosphate, acetic acid, trichloroacetic acid, and sodium hydroxide were pure analytical grade. Whatman filter paper 42 from Merck (Darmstadt, Germany) was used to filtering the sample extract.

\section{Instrumentation}

A Shimadzu-1800 UV-Visible spectrophotometer (Kyoto, Japan) was used to measure the wavelength and absorbance of the complexes formed. ThermoFisher Scientific Eutech $700 \mathrm{pH}$ meter from (Massachusetts, USA) was used to measure the $\mathrm{pH}$ of the buffer solution prepared and standard solution for analytical optimization of solution $\mathrm{pH}$.

\section{Preparation of reagent}

Histamine $(0.1000 \mathrm{~g})$ was weighed and dissolved in methanol, then transferred to a $100 \mathrm{~mL}$ volumetric flask and made up to the mark with the same solvent. $\mathrm{CuSO}_{4} \cdot 6 \mathrm{H}_{2} \mathrm{O}(0.3929 \mathrm{~g})$ was weighed and dissolved in distilled water. The solution was transferred to a $100 \mathrm{~mL}$ volumetric flask and made up to mark with distilled water. $\mathrm{Co}\left(\mathrm{NO}_{3}\right)_{2} \cdot 6 \mathrm{H}_{2} \mathrm{O}(0.4940 \mathrm{~g})$ was weighed and dissolved in distilled water. The solution was transferred to a $100 \mathrm{~mL}$ volumetric flask and made up to mark with distilled water. All solutions were shaken to homogenize. The same procedure was performed for ARS with a weight of 0.1 gram. Buffer solutions used to make an acidic and alkaline 
medium were phosphate buffer solution and acetic buffer solution. Phosphate buffer solution for $\mathrm{pH}$ 6, 7, and 8 was made from $1 \mathrm{M}$ sodium hydrogenphosphate and sodium dihydrogen phosphate solution. While acetic buffer solution for $\mathrm{pH} 4$ and 5 was made from $1 \mathrm{M}$ acetic acid and trichloroacetic acid solution.

\section{Preparation of ARS-metal complex solution}

A $0.25 \mathrm{~mL}$ ARS stock solution $1000 \mathrm{ppm}$ and $1.0 \mathrm{~mL} \mathrm{pH} 7$ buffer solution were transferred quantitatively into a 10 $\mathrm{mL}$ volumetric flask and added with $1.0 \mathrm{~mL} \mathrm{Cu}(\mathrm{II})$ stock solution $1000 \mathrm{ppm}$, respectively. It was made up to the mark with methanol, and shaken until homogeneous and left for $10 \mathrm{~min}$. The wavelength of complex solution formed was scanned from $300-800 \mathrm{~nm}$ and maximum absorbance was noted. The same procedure was repeated for Co(II) solution.

\section{Preparation of histamine-ARS-metal complex solution}

A $0.25 \mathrm{~mL}$ ARS stock solution $1000 \mathrm{ppm}, 1.25 \mathrm{~mL}$ of histamine stock solution $1000 \mathrm{ppm}, 1 \mathrm{~mL}$ buffer solution of pH 7 buffer solution were transferred into a $10 \mathrm{~mL}$ volumetric flask and added with $1.0 \mathrm{~mL}$ Co(II) stock solution $1000 \mathrm{ppm}$, left at room temperature for $10 \mathrm{~min}$. It was made up to mark with methanol. The wavelength of complex solution formed was scanned from $300-800 \mathrm{~nm}$ and maximum absorbance was noted. The same procedure was repeated for $\mathrm{Cu}(\mathrm{II})$ solution.

\section{Optimization of metal concentration}

4 sets of $10 \mathrm{~mL}$ volumetric flask were prepared, and each volumetric flask was added with $1.25 \mathrm{~mL}$ histamine stock solution. In each volumetric flask, then added with $\mathrm{Cu}$ (II) stock solution with variation volume of $0.25 ; 0.50 ; 0.75$; and $1.00 \mathrm{~mL} 1000 \mathrm{ppm}$, hence the concentration of metal was $25,50,75$, and $100 \mathrm{ppm}$; then added with $1.00 \mathrm{~mL} \mathrm{pH}$ 7 buffer solution; and $0.25 \mathrm{~mL}$ ARS stock solution $1000 \mathrm{ppm}$. Another 4 pieces of $10 \mathrm{~mL}$ volumetric flask was added with $1.25 \mathrm{~mL}$ histamine stock solution; then added with $1.00 \mathrm{~mL}$ buffer solution $\mathrm{pH} 7 ; 0.25 \mathrm{~mL}$ alizarin red $\mathrm{S}$ and $1.00 ; 1,25$ and $1,50 \mathrm{~mL}$ of $\mathrm{Co}$ (II) stock solution. Then in each volumetric flask, the solution was diluted with methanol to mark and homogenized. The solution was allowed to stand for 10 minutes and its absorbance was measured at the maximum wavelength. A plot of the relationship between the concentration of alizarin red $\mathrm{S}$ and absorbance was made. The optimum concentration of the metal was obtained from the concentration value of the solution having the greatest absorbance value.

\section{Optimization of ARS concentration}

8 sets of $10 \mathrm{~mL}$ volumetric flask were prepared, and each volumetric flask was added with $1.25 \mathrm{~mL}$ histamine stock solution. In each volumetric flask was added with metal aqueous solution according to the optimum concentration and then added with $1.00 \mathrm{~mL}$ buffer solution $\mathrm{pH} \mathrm{7}$; and $0.25,0.50,0.75$, and $1.00 \mathrm{~mL}$ of ARS stock solution 1000 ppm, hence the concentration of ARS was $25,50,50,75$, and $100 \mathrm{ppm}$. The solution was diluted with methanol to the mark and homogenized. The solution was allowed to stand for 10 minutes and its absorbance was measured at the maximum wavelength. A curve of the relationship between the concentration of red alizarin $\mathrm{S}$ and absorbance was made. The optimum concentration of the metal was obtained from the concentration value of the solution having the greatest absorbance value.

\section{Optimization of pH solution}

10 sets of $10 \mathrm{~mL}$ volumetric flask were prepared. Each volumetric flask was added $1.25 \mathrm{~mL}$ of histamine stock solution and metal aqueous solution according to the optimum concentration, ARS with optimum concentration, and then added with $1.00 \mathrm{~mL}$ buffer $\mathrm{pH}$ solution of $4,5,6,7$, and 8 in each flask. The solution was diluted with methanol to the mark and homogenized. The solution was allowed to stand for 10 minutes and its absorbance measured at the maximum wavelength. A curve of the relationship between the concentration of red alizarin S and absorbance was made. The optimum $\mathrm{pH}$ was obtained from the $\mathrm{pH}$ value of the solution having the greatest absorbance value.

\section{Optimization of time}

10 sets of $10 \mathrm{~mL}$ volumetric flask were prepared, and each volumetric flask was added $1.25 \mathrm{~mL}$ of histamine stock solution. In each volumetric flask was added a solution of metal in accordance with the optimum concentration, ARS with optimum concentration, and then added with $1.00 \mathrm{~mL}$ of optimum buffer $\mathrm{pH}$ solution. The solution was 
allowed to stand for 10 minutes and its absorbance measured at the maximum wavelength. A curve of the relationship between the concentration of red alizarin $\mathrm{S}$ and absorbance was made. The optimum time was obtained from the time value of the solution having the greatest absorbance value.

\section{Determination of histamine in fish}

A sample preparation as follows was tried to detect and determine the histamine in fish fillets according to the previous method [25]. Briefly, $10 \mathrm{~g}$ fish muscle was minced with $10 \mathrm{~mL}$ of $10 \%$ trichloroacetic acid in water using a homogenizer. The homogenate was spiked with histamine standard, resulting in artificial contamination at 50, 100, and $150 \mathrm{mg} / \mathrm{kg}$. The homogenate neutralized by $0.1 \mathrm{~mL} 0.1 \mathrm{M} \mathrm{NaOH}$ solution was centrifuged at $3000 \mathrm{r} / \mathrm{min}$ for 5 minutes. Then $2 \mathrm{~mL}$ of the supernatant was then filtered through a Whatman filter paper 42 . The supernatant then used to determination of histamine in fish sample with the optimum condition for each metal.

\section{Results and Discussion}

A spectrophotometric method for the determination of histamine is based on the complex reaction between histamine, ARS, and metal using an UV-visible spectrophotometer with a concentration of histamine $125 \mathrm{ppm}$, ARS $25 \mathrm{ppm}$, and metal(II) $100 \mathrm{ppm}$ has been done. From Figure 3, it can be seen that the complex compounds of ARS and $\mathrm{Cu}(\mathrm{II})$ and $\mathrm{Co}$ (II) produce maximum wavelength at $544 \mathrm{~nm}$ and $543 \mathrm{~nm}$, respectively. Structure of ARS-metal in various media which has been found before by the simple Hückel method [26] indicates that alizarin complexation occurs at the peri-hydroxy carbonyl group and results in the formation of the $\mathrm{C}=\mathrm{O} \rightarrow \mathrm{M}-\mathrm{O}$ coordination bond as shown in Figure 4(a). In acidic media, O-M bond remains covalent and the electronic absorption spectra of alizarinates are identical to the spectrum of nonionized alizarin as shown in Figure 4(b) in which $\mathrm{H}$ atom is replaced with metal atom. In alkali solution, alizarin reacted with metal ions as the ortho-diphenol compound as shown in Figure 4(c).

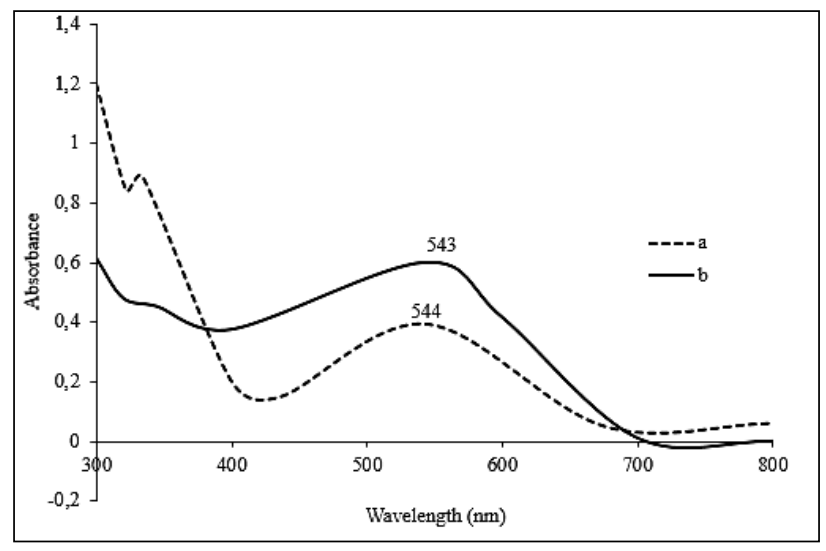

Figure 3. (a) UV-visible spectra of ARS-Cu(II) complex (b) ARS-Co(II) complex

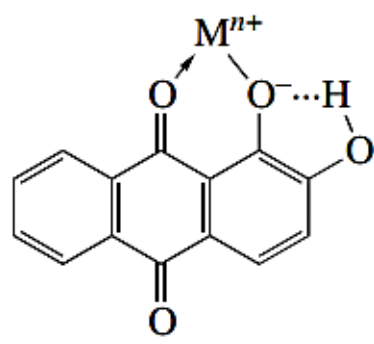

(a)<smiles>O=C1c2ccccc2C(=O)c2c1ccc(O)c2O</smiles>

(b)

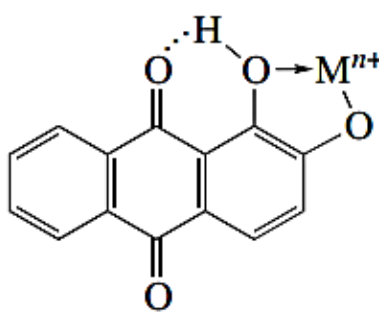

(c)

Figure 4. Structure of ARS complex in various medium (a) neutral medium (b) acidic medium (c) alkaline medium [26] 


\section{Jannatin et al: RAPID SPECTROPHOTOMETRIC METHOD FOR HISTAMINE DETERMINATION IN FISH}

USING ALIZARIN RED S AND METAL

This complex compound will then react with histamine forming a new pink complex compound with a maximum wavelength for $\mathrm{Cu}(\mathrm{II})$ and $\mathrm{Co}(\mathrm{II})$ at $505.5 \mathrm{~nm}$; and $567 \mathrm{~nm}$, respectively. These results indicate that a shift in the wavelength of maximum absorption into lower wavelength due to hypsochromic effect for $\mathrm{Cu}$ (II) and greater due to bathochromic effect for $\mathrm{Co}$ (II) and electron configuration of $\mathrm{Co}$ and $\mathrm{Cu}$ as shown in Figure 5. The metals bind the existing amine group on histamine and carbonyl group of ARS. This compound is predicted that it has an octahedral shaped molecular. Based on crystal field theory, octahedral shape has an energy splitting as shown in Figure 6 when stabilizing energy of metal-ligand complex due to the amount of electrons in $t_{2 g}$ meanwhile unstabilizing energy of metal-ligand complex is due to the amount of electrons e.g. $\mathrm{Cu}$ and $\mathrm{Co}$ have the same amount of electrons in $\mathrm{t}_{2 \mathrm{~g}}$ but it has different amount of electrons e.g. $\mathrm{Cu}$ has three electrons while $\mathrm{Co}$ has an electron there. It means that $\mathrm{Cu}$ is more unstable than $\mathrm{Co}$, so $\mathrm{Cu}$ needed more energy to form the complex than $\mathrm{Co}$. Furthermore, it would give a greater wavelength. In the molecular structure of the complex as shown in Figure 7, histamine acts as a bidentate ligand by chelating the metal ion. The metal is in a square pyramidal geometry defined by two $\mathrm{N}$ atoms of aqua ligand at apex of pyramid. Histamine along with neighboring carbonyl ion participates in weak hydrogen bonds of $\mathrm{N}-\mathrm{H}-\mathrm{O}$ in the crystal packing of $\left[\mathrm{Metal}(\mathrm{His})(\mathrm{ARS})\left(\mathrm{H}_{2} \mathrm{O}\right)_{2}\right]$ complex.

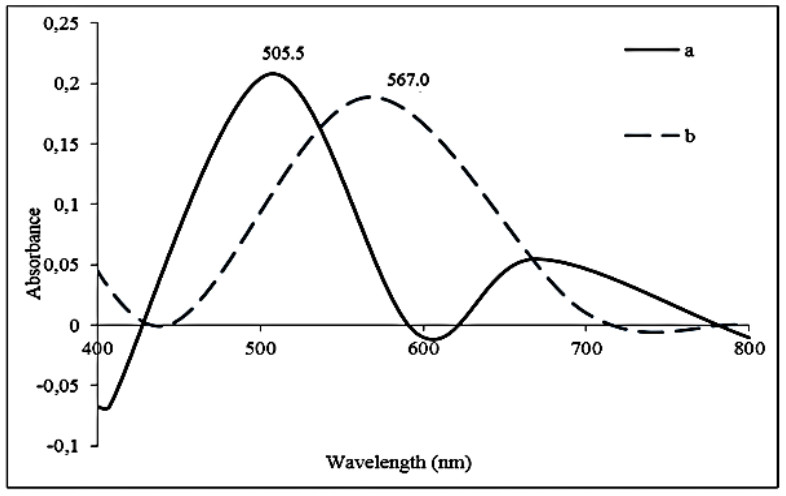

Figure 5. (a) UV-visible spectra of ARS-histamine-Cu(II) complex (b) ARS-histamine-Co(II) complex

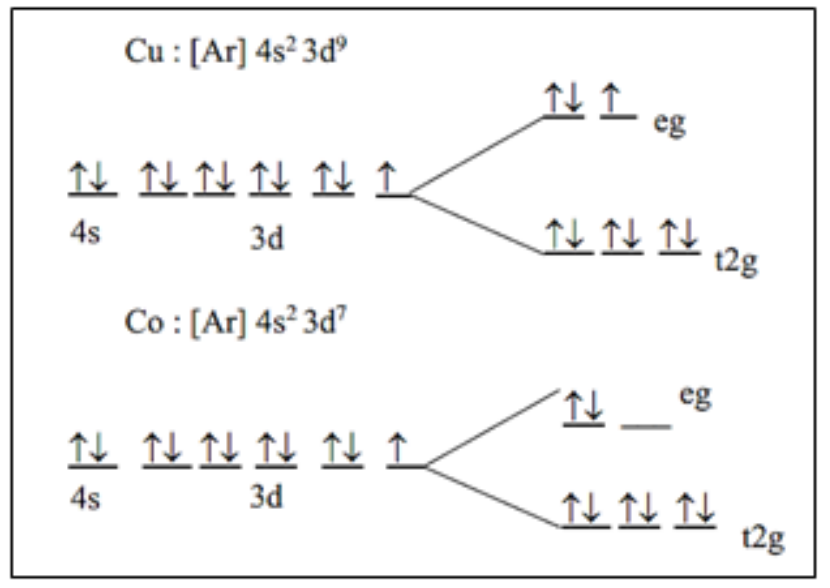

Figure 6. Splitting energy of $\mathrm{Cu}$ and Co due to crystal field theory 


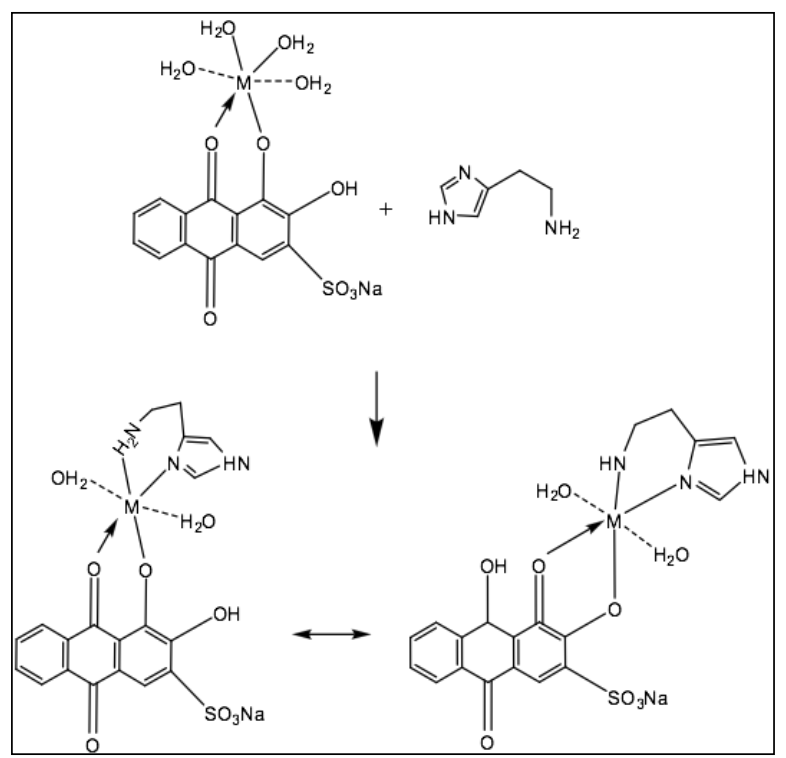

Figure 7. The prediction reaction of metal(II), histamine and ARS

The wavelength of the histamine - ARS - metal complex compound is used as the wavelength for the entire analytical parameter optimization. Optimization of metal and ARS concentration is obtained from the increase in absorbance due to higher concentration. The optimum results of $\mathrm{Cu}$ (II) and $\mathrm{Co}$ (II) concentration are 50 and $125 \mathrm{ppm}$ as shown in Figure 8(a) and (b), respectively. Optimization of ARS for $\mathrm{Cu}(\mathrm{II})$ and $\mathrm{Co}(\mathrm{II})$ complex is $75 \mathrm{ppm}$ as shown in Figure 8(b).
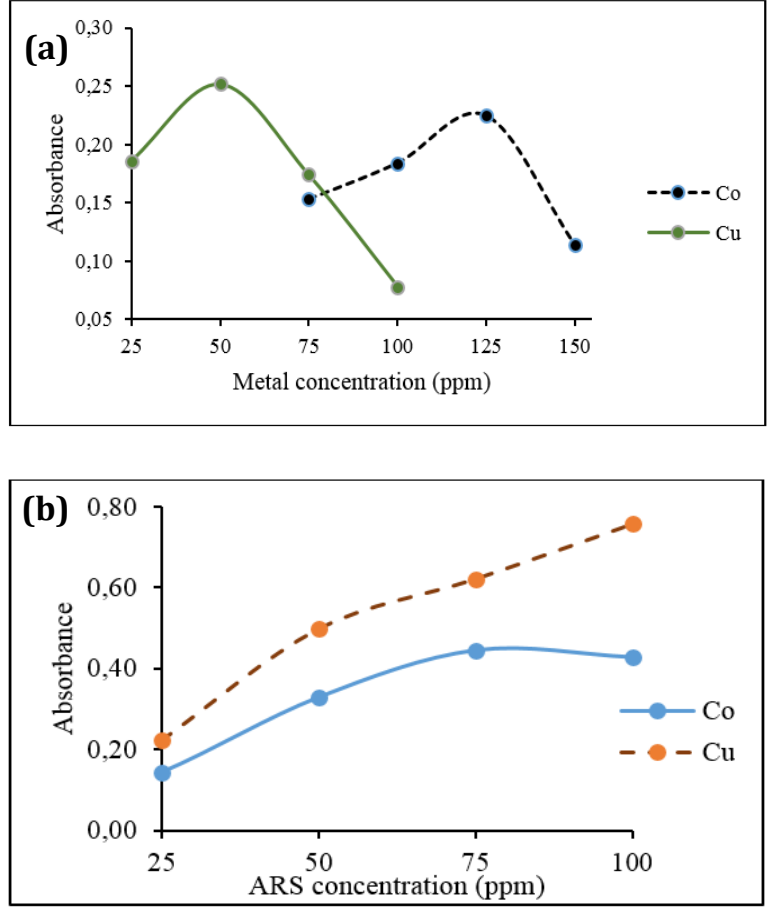

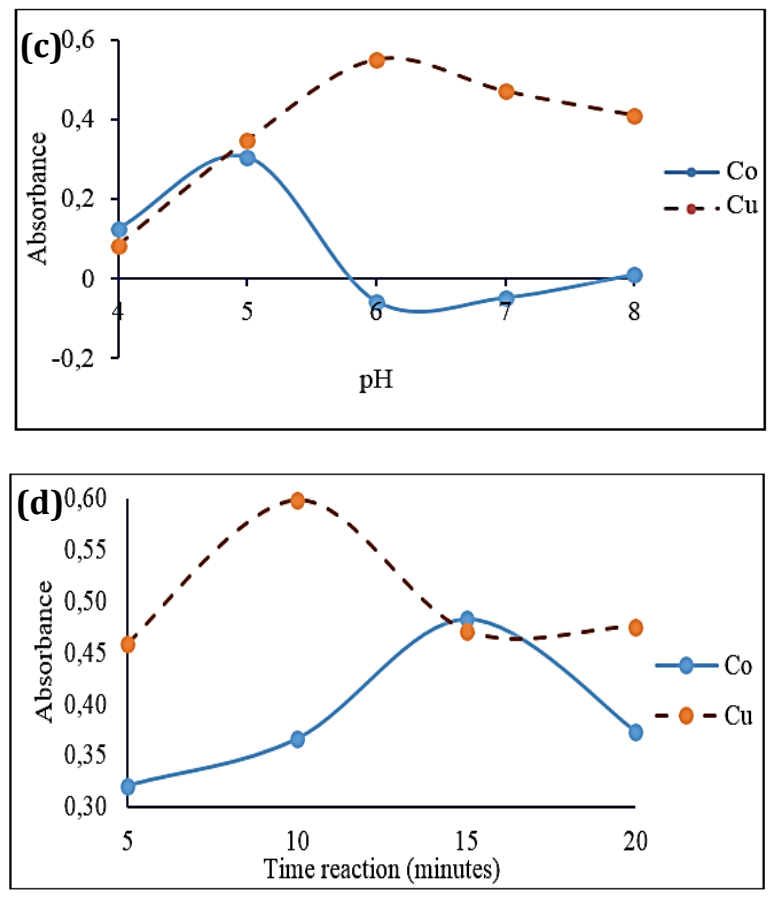

Figure 8. Optimization of (a) metal concentration (b) ARS concentration (c) pH solution (d) time due to the higher absorbance

The optimum $\mathrm{pH}$ for complex formation was determined. In Figure 8(c), it is obtained that $\mathrm{pH}$ optimum is at $\mathrm{pH} 6$ and 5 for $\mathrm{Cu}$ (II) and $\mathrm{Co}(\mathrm{II})$, respectively. The reaction of $\mathrm{Cu}$ (II) and $\mathrm{Co}$ (II) complex formation took place in acidic conditions because in $\mathrm{pH}>7$ histamine - $\mathrm{ARS}-\mathrm{Cu}(\mathrm{II})$ and $\mathrm{pH}>6 \mathrm{Co}$ (II) solution lead the precipitation of $\mathrm{M}(\mathrm{OH})_{2}$ and starts to form colloidal solution. It is because in this condition, $\mathrm{Ksp} \mathrm{M}(\mathrm{OH})_{2}$ has been reached [27]. Time of $\mathrm{Cu}(\mathrm{II})$ and $\mathrm{Co}(\mathrm{II})$ complex are 10 and 15 minutes, respectively, as shown in Figure 8(d).

From the results of the optimization (concentration of ARS and metal(II), $\mathrm{pH}$ and time), linear calibration curves are obtained at the range of $25-150 \mathrm{ppm}$ of histamine as shown in Figure 9. The linear regression for $\mathrm{Cu}$ (II) and $\mathrm{Co}$ (II) is $\mathrm{y}=0.0054 \mathrm{x}-0.1944$ and $\mathrm{R}^{2}=0.9959 ; \mathrm{y}=0.0006 \mathrm{x}+0.3136$ and $\mathrm{R}^{2}=0.9965$, respectively. Validation parameters for each metal are shown in Table 1. Based on linear regression and Table 1, linearity is closed to 1 so it is quite good. Two directions ANOVA shows $\mathrm{t}_{\text {table }}<\mathrm{t}_{\text {calculation, }}$, so $\mathrm{H}_{0}$ is rejected and there is a correlation between the concentration with absorbance. The accuracy of the method range of $101.63 \%$ and $96.01 \%$ for $\mathrm{Cu}$ (II) and $\mathrm{Co}$ (II) complex is shown in the Table 2 so it is indicated that this method of approaching the actual state of histamine concentration. Variation coefficient of histamine by $0.650 \%$ and $0.275 \%$ is shown in Table 3 for each metal. Furthermore, $\mathrm{Cu}(\mathrm{II})$ complex has higher sensitivity than $\mathrm{Co}(\mathrm{II})$ with a sensitivity of 0.0054 ; while sensitivity of $\mathrm{Co}$ (II) complex is 0.0006 obtained from the slope of histamine standard curve. 


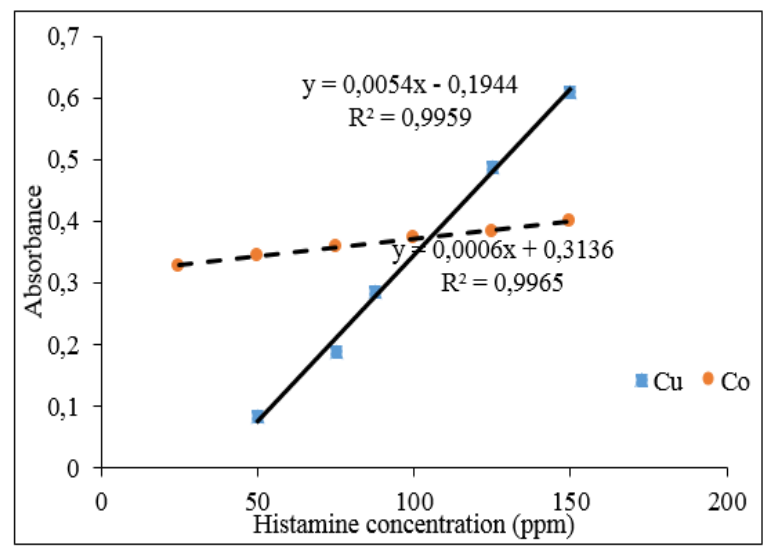

Figure 9. Calibration curve of histamine

Table 1. Validation parameters of method

\begin{tabular}{lcc}
\hline Validation Parameter & \multicolumn{2}{c}{ Result } \\
\hline Metal & $\mathrm{Cu}(\mathrm{II})$ & $\mathrm{Co}(\mathrm{II})$ \\
LOD & $8.94 \mathrm{ppm}$ & $2.58 \mathrm{ppm}$ \\
LOQ & $29.82 \mathrm{ppm}$ & $8.6 \mathrm{ppm}$ \\
Linearity & 0.99 & 0.99 \\
Sensitivity & $0.0054 / \mathrm{ppm}$ (slope) & $0.0006 / \mathrm{ppm}$ (slope) \\
\hline
\end{tabular}

Table 2. Accuracy of method for $\mathrm{Cu}(\mathrm{II})$ and $\mathrm{Co}(\mathrm{II})$ complex

\begin{tabular}{lcccc}
\hline \multirow{2}{*}{$\begin{array}{l}\text { Actual Concentration } \\
(\mathbf{p p m})\end{array}$} & \multicolumn{2}{c}{$\mathbf{C u}(\mathbf{I I})$} & \multicolumn{2}{c}{ Co(II) } \\
\cline { 2 - 5 } & $\begin{array}{c}\text { Found Concentration } \\
(\mathbf{p p m})\end{array}$ & $\begin{array}{c}\text { Recovery } \\
(\boldsymbol{\%})\end{array}$ & $\begin{array}{c}\text { Found Concentration } \\
(\mathbf{p p m})\end{array}$ & $\begin{array}{c}\text { Recovery } \\
(\boldsymbol{\%})\end{array}$ \\
\hline 50 & 52.935 & 105.70 & 49.167 & 98.33 \\
100 & 105.060 & 105.06 & 95.830 & 95.83 \\
150 & 121.513 & 91.12 & 140.830 & 93.88 \\
& Mean & 101.63 & Mean & 96.01 \\
\hline
\end{tabular}

Table 3. Variation coefficient (precision) of histamine standard for $\mathrm{Cu}(\mathrm{II})$ and $\mathrm{Co}$ (II) complex

\begin{tabular}{|c|c|c|c|c|c|c|c|c|c|c|}
\hline \multirow{3}{*}{$\begin{array}{l}\text { Histamine } \\
(\mathrm{ppm})\end{array}$} & \multirow{2}{*}{\multicolumn{4}{|c|}{$\begin{array}{c}\mathrm{Cu}(\mathrm{II}) \\
\text { Absorbance }\end{array}$}} & \multicolumn{6}{|c|}{ Co(II) } \\
\hline & & & & & \multirow{2}{*}{$\begin{array}{c}\text { Precision } \\
(\%)\end{array}$} & \multicolumn{4}{|c|}{ Absorbance } & \multirow{2}{*}{$\begin{array}{c}\text { Precision } \\
(\%)\end{array}$} \\
\hline & $\mathrm{x}_{1}$ & $\mathbf{x}_{2}$ & $\mathbf{x}_{\mathbf{3}}$ & & & $\mathrm{x}_{1}$ & $\mathbf{x}_{2}$ & $\mathbf{x}_{3}$ & & \\
\hline 50 & 0.090 & 0.091 & 0.091 & 0.091 & 0.777 & 0.344 & 0.343 & 0.342 & 0.343 & 0.291 \\
\hline 100 & 0.303 & 0.303 & 0.301 & 0.303 & 0.406 & 0.371 & 0.373 & 0.369 & 0.371 & 0.539 \\
\hline \multirow[t]{2}{*}{150} & 0.566 & 0.565 & 0.573 & 0.568 & 0.767 & 0.398 & 0.398 & 0.398 & 0.398 & 0.000 \\
\hline & \multicolumn{4}{|c|}{ Mean } & 0.650 & \multicolumn{4}{|c|}{ Mean } & 0.275 \\
\hline
\end{tabular}


The optimum result of method has been used for histamine determination in fish. The sample which known previously of histamine levels was spiked using histamine standard solutions at concentrations of 50,100, and 150 $\mathrm{mg} / \mathrm{kg}$. Then the mixed solution was determined using the developed spectrophotometric method as shown in Table 4. Recovery results obtained was close to $100 \%$, it means that both of these metals complexes have a good recovery to be applied to fish samples.

Table 4. Sample application of $\mathrm{Cu}(\mathrm{II})$ and $\mathrm{Co}(\mathrm{II})$ complex

\begin{tabular}{|c|c|c|c|c|}
\hline \multirow[b]{2}{*}{$\begin{array}{l}\text { Real } \\
\text { Concentration } \\
(\mathrm{ppm})\end{array}$} & \multicolumn{2}{|c|}{$\mathrm{Cu}(\mathrm{II})$} & \multicolumn{2}{|c|}{$\mathrm{Co}(\mathrm{II})$} \\
\hline & $\begin{array}{c}\text { Found } \\
\text { Concentration } \\
(\text { ppm) }\end{array}$ & $\begin{array}{c}\text { Recovery }(\%) \\
\quad(n=3)\end{array}$ & $\begin{array}{c}\text { Found } \\
\text { Concentration } \\
(\text { ppm) }\end{array}$ & $\begin{array}{c}\text { Recovery }(\%) \\
(n=3)\end{array}$ \\
\hline Fish & 52 & - & 52 & - \\
\hline Fish +50 & 100 & 97.72 & 105 & 102.71 \\
\hline Fish +100 & 149 & 98.26 & 157 & 103.03 \\
\hline \multirow[t]{2}{*}{ Fish +150} & 202 & 101.71 & 206 & 102.12 \\
\hline & Mean & 99.23 & Mean & 102.62 \\
\hline
\end{tabular}

\section{Conclusion}

The spectrophotometric method for the determination of histamine based on complex reaction using metals and ARS as reagent has been developed which has simple methodology, easy work-up, applicable, and accurate.

\section{Acknowledgement}

The authors are grateful to Analytical Laboratory of Chemistry Department of Universitas Airlangga, Surabaya, Indonesia for providing the facilities to carry out this research work.

\section{References}

1. Kaştaş, G., Paşaoğlu, H., Karabulut, B. and Bulut, İ. (2010). Structural and spectroscopic studies on cadmium complex of a biogenic amine, histamine. Chemical Physics Letters, 488 (4-6): 162-167.

2. Bulushi, I. A., Poole, S., Deeth, H. C. and Dykes, G. A. (2009). Biogenic amines in fish: Roles in intoxication, spoilage, and nitrosamine formation-a review. Critical Reviews in Food Science and Nutrition, 49(4): 369377.

3. Diaz, M., Ladero, V., Redruello, B., Sanchez-Llana, E., Rio, B., Fernandez, M., Martin, M. C. and Alvarez, M. A. (2016). A PCR-DGGE method for the identification of histamine-producing bacteria in cheese. Food Control, 63: 216-223.

4. Altieri, I., Semeraro, A., Scalise, F., Calderari, I. and Stacchini, P. (2016). European official control of food: Determination of histamine in fish products by a HPLC-UV-DAD Method. Food Chemistry. 211: 694-699.

5. Evangelista, W. P., Silva, T. M., Guidi, L. R., Tette, P. A. S., Byrro, R. M. D., Silva, P. S., Fernandes, C. and Gloria, M. B. A. (2016). Quality assurance of histamine analysis in fresh and canned fish. Food Chemistry, 211: 100-106.

6. Veseli, A., Vasjari, M., Arbneshi, T., Hajrizi, A., Svorc, L., Samphao, A. and Kalcher, K. (2016). Electrochemical determination of histamine in fish sauce using heterogeneous carbon electrodes modified with rhenium(iv) oxide. Sensors and Actuators B. 228: 774-781.

7. Department of Health and Human Services, Public Health Service, Food and Drug Administration, Center for Food Safety and Nutrition (2011). Fish and fishery products hazards and controls guidance, $4^{\text {th }}$ edition 2011, April.

8. Lehane, L. and Olley, J. (2000). Review histamine fish poisoning revisited. International Journal of Food Microbiology, 58 (1-2): 1-37. 
9. Keow, C. M., Bakar, F. A., Salleh, A. B., Heng, L. Y., Wagiran, R., Bean, L. S. (2007). An amperometric biosensor for the rapid assessment of histamine level in tiger prawn (Penaeus monodon) spoilage, Food Chemistry, 105(4): 1636-1641.

10. Akbari-adergani, B., Norouzi, P., Ganjali, M. R., and Dinarvand, R. (2010). Ultrasensitive flow-injection electrochemical method for determination of histamine in tuna fish sample. Food Research International Journal, 43(4): 1116-1122.

11. Degefu, H., Amare, M., Tessema, M. and Admassie, S. (2014), Lignin modified glassy carbon electrode for the electrochemical determination of histamine in human urine and wine samples. Electrochimica Acta Journal, 121: 307-314.

12. Tao, Z., Sato, M., Han, Y., Tan, Z., Yamaguchi, T. and Nakano, T. (2011). A simply and rapid method for histamine analysis in fish and fishery products by TLC determination. Food Control, 22(8): 1154-1577.

13. Wang, Z., Wu, J., Wu, S. and Bao, A. (2013). High performance liquid chromatographic determination of histamine in biological samples: the cerebrospinal fluid challenge-a review. Analytica Chimica Acta, 24(774): $1-10$.

14. Henry, B., Gizzi, P. and Delpuech, J. (2015), Magnetic Non-equivalence and dynamic NMR of N-methylene protons in a histamine-containing pseudopeptide: Alanyl-glycyl-histamine. Tetrahedron, 71(36): 6227-6244.

15. An, D., Chen, Z., Zheng, J., Chen, S., Wang, L. and Su, W. (2016). Polyoxometalate functionalized tris(2,2bipyridyl)dichlororuthenium(II) as the probe for electrochemiluminescence sensing of histamine, Food Chemistry, 194: 966-971.

16. Chimalakonda, K. C., Pang, E., Weaver, J. L., Howard, K. E., Patel, V. and Boyne II, M. T. (2015). Development and validation of a liquid-chromatography tandem mass spectrometry method to determine in vitro and in vivo histamine release, Journal of Pharmaceutical and Biomedical Analysis, 102: 494-499.

17. Jancsó, A., Selmeczi, K., Gizzi, P., Nagyc, N. V., Gajda, T. and Henry, B. (2011). The role of terminal amino group and histidine at the fourth position in the metal ion binding of oligopeptides revisited copper(II) and nickel(II) complexes of glycyl-glycyl-glycyl-histamine and its n-boc protected derivative. Journal of Inorganic Biochemistry, 105(1): 92-101.

18. Kaştaş, G., Pasaoglu, H. and Karabulut, B. (2011). Magnetic, structural and computational studies on transition metal complexes of a neurotransmitter, histamine. Journal of Molecular Structure, 1000(1-3): 39-48.

19. Sathish, R. S., Kumar, M. R., Rao, G. N., Kumar, K. A. and Janardhana, C. (2007). A water-soluble fluorescent fluoride ion probe based on ARS-Al(III) complex. Spectrochimica Acta Part A, 66: 457-461.

20. Panahi, H. A., Karimi, M., Moniri, E. and Soudi, H. (2008). Development of a sensitive spectrophotometeric method for determination of copper. African Journal of Pure and Applied Chemistry, 2(10): 96-99.

21. Rohilla, R. and Gupta, U. (2012) Simultaneous determination of cobalt(ii) and nickel(ii) by first order derivative spectrophotometry in micellar media. E-Journal of Chemistry, 9(3): 1357-1363.

22. Gahlan, A. A., El-Mottaleb, M.A., Badawy, N. A., Kamale, F. H. and Ali, S. H. (2014). spectrophotometeric studies on binary and ternary complexes of some metal ions with ARS and cysteine. International Journal of Advanced Research, 2(10): 570-584.

23. Jannatin, M., Supriyanto, G., Pudjiastuti, P. (2017). A novel spectrophotometric method for the determination of histamine based on its complex reaction with $\mathrm{Ni}(\mathrm{II})$ and ARS. Indonesian Journal of Chemistry, 17(1): 139143.

24. Ali, N. M., Amaniampong, P. N. and Karam, A. (2016). Determination of optimal conditions for eelectrodeposition of tin(II) in the presence of ARS. Heliyon, 2(12): 1-26.

25. Xie, Z., Wang, Y., Chen, Y., Xu, X., Jin, Z. and Ding, Y, (2017). Tuneable surface enhanced raman spectroscopy hyphenated to chemically derivatized thin-layer chromatography plates for screening histamine in fish. Food Chemistry, 230: 547-552.

26. Fain, V. Y., Zaitsev, B. E. and Ryabov, M. A. (2004). Metal complexes with alizarin and ARS: Electronic absorption spectra and structure of ligands. Russian Journal of Coordination Chemistry, 30(5): 365-370.

27. Day, R. A. and Underwood, A. L. (2002). Analisis kimia kuantitatif. Edisi keenam. Penerbit Erlangga, Jakarta, Indonesia. 